\title{
PRACA NIEREJESTROWANA JAKO SKUTEK ZJAWISKA BEZROBOCIA WŚRÓD MLODYCH OSÓB W WOJEWÓDZTWIE PODKARPACKIM
}

\begin{abstract}
Transformacja ustrojowa i gospodarcza w Polsce wywołała zasadnicze przeobrażenia rynku pracy. Zjawisko jawnego bezrobocia, nieznane w Polsce przed 1990 r., zaczęło ujawniać się na wielką skalę wraz $\mathrm{z}$ uruchomieniem $\mathrm{w}$ gospodarce mechanizmów rynkowych. Kulminacyjny poziom bezrobocia odnotowano w latach 2002-2005, kiedy w niektórych miesiącach stopa bezrobocia przekraczała 19-20\%. Równocześnie niebezpieczną cechą nie tylko polskiego rynku pracy jest duży odsetek młodych osób pozostających bez pracy.

Konsekwencje bezrobocia najczęściej rozpatruje się na płaszczyźnie ekonomicznej, prawnej oraz politycznej. Nie należy jednak zapominać o stronie zdrowotnej, psychologicznej i obyczajowej $\mathrm{w}$ odniesieniu do pojedynczych osób pozostających bez pracy i ich rodzin. Często skutkiem braku legalnej pracy staje się wybór nielegalnego zatrudnienia jako jedynej dostępnej alternatywy. Jednym z regionów znacząco dotkniętych problemem braku pracy jest województwo podkarpackie.

W publikacji zaprezentowano istotę i skalę nielegalnej pracy w Polsce i województwie podkarpackim. Opisano skutki społeczne i ekonomiczne bezrobocia, a także poziom bezrobocia według struktury wiekowej na Podkarpaciu. Celem publikacji jest próba oceny, czy nielegalna praca jest skutkiem narastającego w ostatnich latach zjawiska bezrobocia wśród młodych osób mieszkających w województwie podkarpackim.

Słowa kluczowe: rynek pracy, praca nierejestrowana, bezrobocie.
\end{abstract}

\section{WPROWADZENIE}

Problem bezrobocia dotyka z różnym natężeniem poszczególnych regionów kraju, ale występuje od lat w całej Polsce. Równocześnie niebezpieczną cechą, nie tylko polskiego rynku pracy, jest duży odsetek młodych osób pozostających bez zatrudnienia. Transformacja ustrojowa i gospodarcza w Polsce wywołała zasadnicze przeobrażenia rynku pracy. Zjawisko jawnego bezrobocia, nieznane w Polsce przed 1990 r., zaczęło się ujawniać na wielką skalę wraz $\mathrm{z}$ uruchomieniem w gospodarce mechanizmów rynkowych. Kulminacyjny poziom bezrobocia odnotowano w latach 2002-2005, kiedy w niektórych miesiącach stopa bezrobocia przekraczała 19-20\%. Po roku 2008 problemy na rynku pracy ponownie pogłębiło spowolnienie gospodarcze wywołane kryzysem subprime. Równocześnie od lat wprowadza się nowe technologie, dokonuje restrukturyzacji przemysłu i zmian w organizacji pracy, co wpływa na ograniczenie zapotrzebowania na siłę roboczą i przekłada się na poziom zatrudnienia.

\footnotetext{
${ }^{1}$ Dr Monika Pasternak-Malicka, Politechnika Rzeszowska, Wydział Zarządzania, Zakład Finansów i Bankowości, Al. Powstańców Warszawy 10, 35-959 Rzeszów, tel.: (17) 86519 12, e-mail: malicka@prz.edu.pl
} 
Konsekwencje bezrobocia najczęściej rozpatruje się na płaszczyźnie ekonomicznej, prawnej oraz politycznej. Nie należy jednak zapominać o stronie zdrowotnej, psychologicznej i obyczajowej w odniesieniu do pojedynczych osób pozostających bez pracy i ich rodzin. Często skutkiem braku legalnej pracy staje się wybór nielegalnego zatrudnienia jako jedynej dostępnej alternatywy. Jednym $\mathrm{z}$ regionów znacząco dotkniętych problemem braku pracy jest województwo podkarpackie.

W publikacji zaprezentowano istotę i skalę nielegalnej pracy w Polsce i województwie podkarpackim. Opisano ekonomiczne, społeczne i psychologiczne skutki bezrobocia, a także poziom bezrobocia według struktury wiekowej na Podkarpaciu. Celem publikacji jest próba oceny, czy nielegalna praca jest skutkiem narastającego w ostatnich latach zjawiska bezrobocia wśród młodych osób mieszkających w województwie podkarpackim. Na podstawie danych statystycznych dokonano próby oceny wpływu poziomu bezrobocia wśród młodych osób na aktywność na nieformalnym rynku pracy przy użyciu metody regresji liniowej. Zaprezentowano także fragmenty własnych badań ankietowych z lat 2007-2014 dotyczących szarej strefy, w tym pracy nieformalnej.

\section{POJĘCIE I SKALA PRACY NIEREJESTROWANEJ W WOJEWÓDZTWIE PODKARPACKIM NA TLE POLSKI}

Przez pojęcie pracy nierejestrowanej (nielegalnej, nieformalnej) najczęściej rozumie się pracę najemną wykonywaną bez zawarcia formalnej umowy, a także pracę wykonywaną w podstawowym miejscu pracy, ale w której ramach wynagrodzenie jest częściowo wypłacane poza ewidencją, oraz nieewidencjonowaną pracę na własny rachunek.

W Polsce szacunków skali nieformalnego zatrudnienia dokonuje Główny Urząd Statystyczny, który rachunki produktu krajowego brutto zestawia zgodnie z wymogami systemu rachunków narodowych i regionalnych ESA'95. Z zasad systemu rachunków narodowych ESA'95, obowiązującego w krajach Unii Europejskiej, wynika jednoznacznie konieczność uwzględnienia, oprócz produkcji bezpośrednio obserwowalnej, również aktywności nieobserwowalnej, w tym szarej strefy gospodarki. Szara gospodarka dotyczy zarówno produkcji ukrytej, jak i nielegalnej. W obecnej praktyce $^{2}$ kraje UE nie uwzględniają produkcji przestępczej. W celu zapewnienia porównywalności szacunków polskie rachunki narodowe uwzględniają jedynie tę część gospodarki ukrytej, która jest bądź mogłaby być legalna ${ }^{3}$. Na takie wyłączenie wskazują także w swoich pracach Friedrich Schneider, Benno Fogler, którzy nie obejmują w swoich wyliczeniach aktywności przestępczej ${ }^{4}$.

\footnotetext{
${ }^{2}$ Rozporządzenie Parlamentu Europejskiego i Rady Europy nakazuje, aby najpóźniej do września 2014 r. kraje członkowskie uwzględniały także nielegalną szarą strefę, na przykład przemyt, prostytucja, handel narkotykami.

${ }^{3}$ Rachunki narodowe wg sektorów i podsektorów instytucjonalnych 2005-2008, Aneks 4: Szara strefa $w$ rachunkach narodowych, Warszawa 2010, s. 387-392. W publikacji zmieniono sposób prezentacji szarej gospodarki, zamieszczając jej udział w produkcie krajowym brutto (PKB łącznie z „szarą strefą" $=100$ ) przy zachowaniu dotychczasowej metody obliczeń. Natomiast we wcześniejszych wydaniach prezentowano udział szarej gospodarki w tworzeniu PKB brutto przyjmując za $100 \%$ PKB bez szarej strefy.

${ }^{4}$ F. Schneider, Shadow Economies and Corruption All Over the World: New Estimates for 145 Countries, Johannes Kepler University of Linz, Austria, 24 July 2007; B. Torgler, F. Schneider,
} 
Tabela 1. Szara strefa gospodarki oraz praca nielegalna według GUS i Friedricha Schneidera w Polsce w latach 2000-2013 (\%)

\begin{tabular}{|l|c|c|c|c|c|c|c|c|c|c|c|c|c|c|}
\hline & $\mathbf{2 0 0 0}$ & $\mathbf{2 0 0 1}$ & $\mathbf{2 0 0 2}$ & $\mathbf{2 0 0 3}$ & $\mathbf{2 0 0 4}$ & $\mathbf{2 0 0 5}$ & $\mathbf{2 0 0 6}$ & $\mathbf{2 0 0 7}$ & $\mathbf{2 0 0 8}$ & $\mathbf{2 0 0 9}$ & $\mathbf{2 0 1 0}$ & $\mathbf{2 0 1 1}$ & $\mathbf{2 0 1 2}$ & $\mathbf{2 0 1 3}$ \\
\hline $\begin{array}{l}\text { Szara } \\
\text { gospodarka } \\
\text { według } \\
\text { GUS }\end{array}$ & 17,0 & 16,3 & 15,3 & 15,4 & 14,4 & 13,7 & 13,7 & 12,8 & 11,8 & 13,1 & 12,8 & 12,6 & - & - \\
\hline $\begin{array}{l}- \text { w tym } \\
\text { praca } \\
\text { nielegalna* }\end{array}$ & 5,3 & 5,2 & 5,2 & 5,1 & 4,9 & 4,2 & 4,0 & 3,6 & 3,5 & 3,5 & 3,3 & 3,2 & - & - \\
\hline $\begin{array}{l}\text { Szara } \\
\text { gospodarka } \\
\text { według } \\
\text { Schneidera }\end{array}$ & 27,6 & 28,2 & 28,9 & 27,7 & 27,4 & 27,1 & 26,8 & 26,0 & 25,3 & 25,9 & 25,4 & 25,0 & 24,4 & 23,8 \\
\hline $\begin{array}{l}- \text { w tym } \\
\text { praca } \\
\text { nielegalna* }\end{array}$ & 9,2 & 9,4 & 9,6 & 9,2 & 9,1 & 9,0 & 8,9 & 8,7 & 8,4 & 8,6 & 8,5 & 8,3 & 8,1 & 7,9 \\
\hline
\end{tabular}

* Przyjęto wskaźniki procentowe na poziomie 1/3 udziału szarej strefy w PKB.

Źródło: Opracowanie własne na podstawie: F. Shneider, The Size of the Shadow Economies of 145 Countries all over the World, First Results over the Period 1999 to 2003, IZA, Discussion Paper No. 1431, 2004 ; F. Schneider, Size and Development of the Shadow Economy of 31 European and 5 other OECD Countries from 2003 to 2013, www. uni-linz.ac.at, april 2013.

Praca nieformalna stanowi istotny element polskiego rynku pracy. W tabeli 1 przedstawiono udział szarej gospodarki, w tym pracy nierejestrowanej, w tworzeniu PKB w latach 2000-2011 według szacunków Głównego Urzędu Statystycznego oraz Friedricha Schneidera w latach 2000-2013. Według GUS udział ten kształtował się w badanym okresie na poziomie od $5,3 \%$ do $3,2 \%$ PKB i wykazywał tendencję malejąca. W analizowanych latach większy wpływ na rozmiary aktywności w strefie nieformalnej miała działalność gospodarcza prowadzona w zarejestrowanych podmiotach gospodarczych. Największy udział w szarej strefie miały podmioty prowadzące działalność handlową, budowlaną oraz obsługi rynku nieruchomości.

Natomiast szacunki Schneidera wskazują na szerszy zakres pracy nieformalnej w Polsce, który utrzymywał się na poziomie wyższym średnio o 4-5 punktów procentowych. Ponadto wskaźnik ten charakteryzował się już bardziej zmienną dynamiką - do 2002 r. odnotowano wzrost - w kolejnych latach, wraz z poprawą koniunktury, zakres pracy nierejestrowanej zmalał do 8,4\% PKB w 2008 r., po czym wraz z spowolnieniem gospodarczym, będącym skutkiem kryzysu subprime, wskaźnik wzrósł nieznacznie w kolejnym roku, aby ponownie obniżyć się do poziomu 7,9\% PKB w 2013 r.

Praca nierejestrowana jako jeden z obszarów gospodarki nieformalnej według badań GUS stanowi około 1/3 wartości szarej strefy. Dane zawarte w tabeli 2 przedstawiają, jak zmieniał się nominalnie poziom pracy nierejestrowanej w latach 1994-2011. Szacuje się, że wartość wytworzonych dóbr i usług z tytułu wykonywania pracy nierejestrowanej wynosiła od 10731 do $48900 \mathrm{mln}$ zł rocznie w badanym okresie. Gdyby przyjąć utrzymującą się stopę szarej gospodarki z $2011 \mathrm{r}$. na poziomie 12,6\% ${ }^{5} \mathrm{w}$ poprzednim

Shadow Economy, Tax Morale, Governance and Institutional Quality: A panel Analysis, „IZA Discussion Paper Series" 2007, s. 9-10.

${ }^{5} \mathrm{~W}$ tym 3,2\% stanowi udział w szarej strefie $\mathrm{z}$ tytułu wykonywania pracy nierejestrowanej. 
roku, to dla PKB wynoszącego $1631764 \mathrm{mln}$ zł praca nierejestrowana osiagnnęłaby poziom $52216,5 \mathrm{mln}$ zł w $2013 \mathrm{r}$.

Tabela 2. Szara strefa gospodarki w Polsce według Głównego Urzędu Statystycznego w latach 1994-2011 w cenach bieżących (mln)

\begin{tabular}{|l|c|c|c|c|c|c|c|c|c|}
\hline & $\mathbf{1 9 4}$ & $\mathbf{1 9 9 5}$ & $\mathbf{1 9 9 6}$ & $\mathbf{1 9 9 7}$ & $\mathbf{1 9 9 8}$ & $\mathbf{1 9 9 9}$ & $\mathbf{2 0 0 0}$ & $\mathbf{2 0 0 1}$ & $\mathbf{2 0 2}$ \\
\hline $\begin{array}{l}\text { Produkt krajowy } \\
\text { brutto }\end{array}$ & 210407 & 308103 & 387827 & 472350 & 553560 & 615560 & 744378 & 779563 & 808578 \\
\hline $\begin{array}{l}- \text { praca } \\
\text { nierejestrowana }\end{array}$ & 10731 & 14481 & 17840 & 19839 & 23803 & 25238 & 39452 & 40537 & 42046 \\
\hline & $\mathbf{2 0 0 3}$ & $\mathbf{2 0 0 4}$ & $\mathbf{2 0 0 5 *}$ & $\mathbf{2 0 0 6}$ & $\mathbf{2 0 0 7}$ & $\mathbf{2 0 0 8}$ & $\mathbf{2 0 0 9}$ & $\mathbf{2 0 1 0}$ & $\mathbf{2 0 1 1}$ \\
\hline $\begin{array}{l}\text { Produkt krajowy } \\
\text { brutto }\end{array}$ & 843156 & 924538 & 983302 & $\begin{array}{r}106003 \\
1\end{array}$ & $\begin{array}{r}117673 \\
7\end{array}$ & $\begin{array}{r}127550 \\
8\end{array}$ & $\begin{array}{r}134450 \\
5\end{array}$ & $\begin{array}{r}141658 \\
5\end{array}$ & 1528127 \\
\hline $\begin{array}{l}\text { - praca } \\
\text { nierejestrowana* }\end{array}$ & 43000 & 45302 & 41299 & 42401 & 42363 & 44643 & 47058 & 46747 & 48900 \\
\hline
\end{tabular}

* Od 2005 r. PKB łącznie z szarą gospodarką.

Źródło: Opracowanie własne na podstawie: Rachunki narodowe wg sektorów i podsektorów instytucjonalnych, GUS z lat 1995-2013.

Tabela 3. Szara strefa gospodarki w wojedwództwie podkarpackim według Głównego Urzędu Statystycznego w latach 1994-2011 w cenach bieżących (mln)

\begin{tabular}{|c|c|c|c|c|c|c|c|c|c|}
\hline & 1994 & 1995 & 1996 & 1997 & 1998 & 1999 & 2000 & 2001 & 2002 \\
\hline $\begin{array}{l}\text { Produkt krajowy } \\
\text { brutto }\end{array}$ & 8840 & 12999,4 & 16297,0 & 19955,7 & 23037,1 & 24815,6 & 28514,0 & 30184 & 31188 \\
\hline $\begin{array}{l}\text { - praca } \\
\text { nierejestrowana** }\end{array}$ & 450,8 & 610,97 & 749,66 & 838,14 & 990,60 & 1017,44 & 1511,24 & 156957 & 1621,78 \\
\hline & 2003 & 2004 & 2005* & 2006 & 2007 & 2008 & 2009 & 2010 & 2011 \\
\hline $\begin{array}{l}\text { Produkt krajowy } \\
\text { brutto* }\end{array}$ & 32780 & 35416 & 37564 & 39894 & 43823 & 48385 & 50740 & 52522 & 57028 \\
\hline $\begin{array}{l}\text { - praca } \\
\text { nierejestrowana** }\end{array}$ & 1671,78 & 173538 & 1577,69 & 1595,76 & 157,63 & 1693,48 & 1775,90 & 1733,2 & 182490 \\
\hline
\end{tabular}

* Od 2005 r. PKB łącznie z szarą gospodarką; ** Szacowana jako 1/3 PKB.

Źródło: Opracowanie własne na podstawie: Rachunki narodowe wg sektorów i podsektorów instytucjonalnych, GUS z lat 1995-2013.

W tabeli 3 zaprezentowano zakres szarej strefy gospodarki oraz rozmiary pracy nierejestrowanej w latach 1994-2011 na terenie Podkarpacia. Wielkości podane w cenach bieżących obliczono dla wspomnianego okresu na podstawie danych procentowych GUS określonych dla Polski.

Departament Rachunków Narodowych GUS nie dysponuje danymi szacunkowymi dotyczącymi szarej strefy i pracy nieformalnej na poziomie województw (nie dokonuje się takich wyliczeń). Po konsultacji z departamentem rachunków narodowych uznano, że udział procentowy szarej strefy w PKB w województwie podkarpackim odpowiada wielkościom obliczonym dla całego kraju. Ponieważ więc nie jest szacowana wielkość (ani procentowo, ani nominalnie) szarej strefy w PKB na poziomie województw, dlatego według sugestii wspomnianego departamentu przyjęto wskaźniki procentowe obliczane dla Polski i odniesiono je do PKB Podkarpacia.

\section{EKONOMICZNE SKUTKI BEZROBOCIA}

Skutki bezrobocia najczęściej dzieli się na: ekonomiczne, społeczne, psychologiczne oraz polityczne, których klasyfikacja jest niekiedy utrudniona, gdyż poszczególne wymienione sfery nakładają się na siebie. W literaturze przedmiotu można także się spotkać z rozróżnieniem na mikroekonomiczne (jednostkowe) oraz makroekonomiczne (dotyczące całego kraju bądź całego społeczeństwa) konsekwencje zjawiska bezrobocia. 
Bezrobocie jest powszechnie uznawane za zjawisko negatywne, jednak można dostrzec także jego pozytywne skutki, takie jak motywacja do kształcenia, poprawa dyscypliny pracy, przyspieszenie procesów wzrostu kwalifikacji zawodowych siły roboczej, co przekłada się na długookresowy wzrost gospodarczy ${ }^{6}$. Bezrobocie odgrywa też istotną rolę w przekształceniach strukturalnych gospodarki, wynikających z różnej branżowej dynamiki postępu technicznego, zmieniającego się zapotrzebowania na pracę oraz zmian w strukturze popytu na towary i usługi ${ }^{7}$. Wyższe bezrobocie prowadzi do osłabienia pozycji pracowników i związków zawodowych, co przekłada się na osłabienie procesów inflacyjnych.

Najistotniejszym ekonomicznym skutkiem bezrobocia, a jednocześnie największym kosztem społecznym wynikającym z tego zjawiska jest strata PKB. Wielkość tej straty określana jest jako luka PKB, czyli różnica między potencjalnym PKB (występującym w warunkach pełnego zatrudnienia) a rzeczywistym $\mathrm{PKB}^{8}$. Związek między wzrostem stopy bezrobocia ponad jej poziom naturalny a wynikającymi z tego tytułu stratami PKB badał Arthur Okun, który sformułował zależność obecnie znaną w literaturze pod nazwą prawo Okuna. Określa ono, że wzrost bezrobocia o jeden punkt procentowy pociąga za sobą spadek PKB w ujęciu rzeczowym o około trzy punkty procentowe?

Wśród skutków ekonomicznych najczęściej wymienia się także obciążenia finansowe państwa związane z wydatkami na osoby bezrobotne. Kosztami bezpośrednimi są zasiłki i inne koszty wynikające $\mathrm{z}$ funkcjonowania instytucji zajmujących się zwalczaniem bezrobocia. Jednocześnie powoduje to ograniczenie wydatków na programy przeciwdziałania bezrobociu i zwiększanie funduszy na pomoc społeczną ${ }^{10}$.

Koszty pośrednie związane są z utratą przychodów budżetowych z tytułu płaconych podatków (bezpośrednich i pośrednich) oraz składek na ubezpieczenia społeczne. Ponadto wysokie bezrobocie pociagga za sobą zwiększone wydatki na utrzymanie policji, służby zdrowia czy też szkolnictwa ${ }^{11}$.

Ograniczona dynamika wzrostu PKB wpływa nie tylko na spadek dochodów państwa, ale także na dochody gospodarstw domowych i podmiotów gospodarczych, co z kolei prowadzi do obniżenia poziomu oszczędności, a tym samym - ogranicza możliwości inwestycyjnych i produkcyjnych ${ }^{12}$.

${ }^{6}$ R.J. Barro, Economic Growth in a Cross Selection of Countries, "Quarterly Journal of Economics", May 1991.

${ }^{7}$ E. Kwiatkowski, Bezrobocie. Podstawy teoretyczne, PWN, Warszawa 2002, s. 78.

8 E. Kubiak, H. Nakonieczna-Kisiel, Makroekonomiczne podstawy polityki gospodarczej, Wydawnictwo Samorządowe FRDL, Warszawa 1999, s. 230.

${ }^{9}$ R.E. Hall, J.B. Taylor, Makroekonomia, PWN, Warszawa 2002, s. 147; A.M. Okun, Ceny i ilości. Analiza makroekonomiczna, PWN, Warszawa 1991.

${ }^{10}$ Osoby zdrowe mogące pracować stają się biorcami pomocy państwa i obciążeniem dla budżetu. Por. Nowe zadania polityki społecznej. Patologie $i$ dysfunkcje wybranych obszarów życia spotecznego, red. E. Trafiałek, PWSZ, Tarnobrzeg 2006, s. 136; M. Mindur, Kontrowersje i sporne kwestie dotyczace bezrobocia w Polsce, „Studia i prace Kolegium Zarządzania i Finansów SGH" 2007/84, s. 20.

${ }^{11}$ M. Kabaj, Strategie i programy przeciwdziałaniu bezrobociu $w$ Unii Europejskiej $i$ w Polsce, SCHOLAR, Warszawa 2004, s. 149.

12 M. Cieślukowski, Ekonomiczne skutki i metody ograniczania bezrobocia, „Ruch Prawniczy, Ekonomiczny i Społeczny” 1998/3-4, s. 261. 
Do negatywnych następstw braku pracy zalicza się także straty związane z migracją ludności, zwłaszcza młodego pokolenia ${ }^{13}$. Globalizacja i integracja z UE umożliwiła łatwiejsze przemieszczanie się ludności, co spowodowało emigrację w celach zarobkowych osób z wyższym wykształceniem lub dobrze wykwalifikowanych, które nie mogły znaleźć pracy na terenie kraju ${ }^{14}$.

W literaturze wskazuje się, że bezrobocie może stanowić czynnik motywujący do aktywności w szarej strefie, w tym do podejmowania zatrudnienia nierejestrowanego. Do podobnych wniosków prowadzą badania ankietowe BAEL w latach 1995-2010. Ze struktury odpowiedzi wynika, że oprócz motywu finansowego i niewystarczających zarobków, brak możliwości znalezienia pracy był wskazywany najczęściej jako przyczyna pracy nierejestrowanej. Podobnie analiza CASE oraz badania Instytutu Pracy i Spraw Socjalnych pozwoliła wskazać zależność między poziomem bezrobocia a szarą strefą ${ }^{15}$.

\section{SPOŁECZNE I PSYCHOLOGICZNE SKUTKI BRAKU PRACY}

Społeczne skutki bezrobocia dotyczą przede wszystkim strony materialnej bezrobotnego i jego najbliższych, a w konsekwencji prowadzą do zaburzeń w funkcjonowaniu rodziny. Utrata pracy wpływa na spadek dochodów, a długotrwałe pozostawanie bez zatrudnienia może prowadzić do ubóstwa, a nawet dziedziczenia bezrobocia. Zagrożenie materialne własne i rodziny łączy się z destabilizacją życia rodzinnego. Trzeba zmienić przyzwyczajenia konsumpcyjne i towarzyskie, aby przystosować się do nowej sytuacji. Przekłada się to często na aspiracje edukacyjne dzieci.

Bezrobocie w psychologii traktowane jest jako doświadczenie wysoce stresujące, powodujące zmianę dotychczasowych wzorców zachowania. Jest to sytuacja deprymująca, gdyż dana osoba nie ma na nią wpływu. W psychologii panuje pogląd, że jest to szczególny rodzaj stresu, porównywalny nawet ze śmiercią kogoś bliskiego.

Utrata pracy wpływa także na kontakty bezrobotnych $\mathrm{z}$ otoczeniem społecznym. Wpływ ten jest tym silniejszy, im bardziej wykonywanie dotychczasowej pracy związane było z siecią kontaktów społecznych. W momencie kiedy urywają się związki z dotychczasowymi znajomymi, często pochodzącymi z kręgów zawodowych, pojawia się poczucie izolacji społecznej, któremu często towarzyszy stan depresji psychicznej ${ }^{16}$.

13 M. Pasternak-Malicka, Przyczyny i skutki migracji zagranicznych młodych Polaków, [w:] Wspótczesne problemy ekonomiczne, „Zeszyty Naukowe Uniwersytetu Szczecińskiego" 2013/787, s. 179-190; M. Pasternak-Malicka, Przestanki ruchów migracyjnych Polaków z obszaru województwa podkarpackiego $w$ kontekście kryzysu gospodarczego wywołanego kryzysem subprime, „Ekonomia, Prace Naukowe Uniwersytetu Ekonomicznego we Wrocławiu” 2013/305, s. 536-546.

${ }^{14}$ Rynek pracy $w$ Polsce $w$ dobie integracji i globalizacji, red. M. Noga, M.K. Sawicka, Cedetu, Warszawa 2009, s. 55.

${ }^{15}$ Pasternak-Malicka M., Zatrudnienie nierejestrowane $w$ kontekście problematyki bezrobocia, [w:] Praca Polaków, red. B. Kłos, A. Grycuka, Biuro Analiz Sejmowych Kancelarii Sejmu, Studia BAS, 4(36), Warszawa 2013, s. 27-56.

${ }^{16}$ Stan taki pogłębia medialny wizerunek bezrobotnego wynikający często z niezwykle liberalnych zasad przyznawania zasiłków w początkowej fazie transformacji gospodarki, które wręcz zachęcały do nadużyć. Por. M. Socha, U. Sztanderska, Strukturalne podstawy bezrobocia w Polsce, PWN, Warszawa 2002, s. 92-95. 
Osoba pozostająca bez pracy często charakteryzuje się obniżeniem ogólnej aktywności życiowej oraz brakiem odpowiedniej strukturalizacji działań i czasu. Towarzyszą temu wspomniane poczucie bezcelowości i zwiększona wrażliwość na porażki. Badania wykazują istotny związek między bezrobociem a rosnącą liczbą chorób psychicznych, psychosomatycznych i zaburzeń osobowości. Z amerykańskich badań wynika natomiast zbieżność wskaźnika bezrobocia z zaburzeniami sercowo-naczyniowymi, marskością wątroby, alkoholizmem. Przy długotrwałym okresie pozostawania bez pracy wzrasta też liczba samobójstw i prób samobójczych.

Z badań ankietowych przeprowadzonych przez Instytut Pracy i Spraw Socjalnych (IPiSS) wynika, że oprócz zubożenia materialnego bezrobocie wywoływało wiele następstw społeczno-psychologicznych, na przykład ponad połowa respondentów zrezygnowała z życia towarzyskiego, u $38 \%$ badanych w rodzinach narastały konflikty, a $12 \% \mathrm{z}$ nich zwróciło uwagę na utratę własnej wartości ${ }^{17}$.

Bezrobocie wywiera bardzo duże negatywne konsekwencje na ludzi młodych o jeszcze nie do końca ukształtowanej osobowości. Brak pracy, perspektyw oraz możliwości założenia własnej rodziny mogą prowadzić do apatii, niewiary w przyszłość, obniżenia aspiracji edukacyjnych ${ }^{18}$. Takie postawy mogą spowodować rezygnację z prób podjęcia pracy, a nawet ostatecznie mogą wywołać zachowania patologiczne, takie jak narkomania, prostytucja, podejmowanie zajęć niezgodnych $\mathrm{Z}$ prawem, a nawet przestępczych $^{19}$.

Młodzi bezrobotni są grupą najbardziej zagrożoną skutkami dezaktywizacji zawodowej. W tej kategorii wiekowej obserwuje się trwałe i groźne społecznie zmiany w psychice, takie jak frustracja, obojętność, zahamowanie rozwoju osobowości, lęk o przyszłość, które w rezultacie prowadzą do zachowań patologicznych.

\section{BEZROBOCIE WEDLUG STRUKTURY WIEKOWEJ W WOJEWÓDZTWIE PODKARPACKIM}

Sytuacja na rynku pracy w województwie podkarpackim jest trudna. To region słabszy pod względem rozwoju gospodarczego, rolniczy i z rozdrobnionymi usługami, choć $\mathrm{z}$ rozwijającym się przemysłem lotniczym. Wysokość stopy bezrobocia na Podkarpaciu, w porównaniu $\mathrm{z}$ innymi województwami, jest dość wysoka ${ }^{20}$. W ostatnich latach, według BAEL, region ten utrzymywał się w pierwszej trójce pod względem wysokości tego wskaźnika - jesienią 2013 r. najtrudniej było o pracę na Podkarpaciu. W

${ }^{17}$ E. Bąk, Nietypowe formy zatrudnienia na rynku pracy, C.H. Beck, Warszawa 2009, s. 146.

${ }^{18}$ Z. Dach, Bezrobocie w okresie przemian systemowych gospodarki polskiej, PAN, Warszawa 1993, s. 65

19 Wzrost przestępczości jako skutek bezrobocia bywa niekiedy kwestionowany. Postawy przestępcze zależą od bardzo różnorodnych czynników, tak jak nie ma jednolitej koncepcji wyjaśniającej fenomen zła jako personalnego doświadczenia każdej istoty ludzkiej. Por. J. Stecko, Prywacyjna koncepcja zła w interpretacji Leszka Kołakowskiego, „Humanities and Social Sciences" 20/1 (2013), s. 97-103; J. Stecko, W poszukiwaniu pierwszej przyczyny zła - filozofia Mariana Zdziechowskiego, „Humanities and Social Sciences” 20/3 (2013), s. 187-192.

${ }^{20} \mathrm{~W}$ województwie podkarpackim występuje także większe niż $\mathrm{w}$ innych regionach kraju bezrobocie ukryte, które dotyczy głównie terenów wiejskich oraz słabo zurbanizowanych. Por. Analiza sytuacji na rynku pracy w województwie podkarpackim, Wojewódzki Urząd Pracy w Rzeszowie, Rzeszów 2012, s. 11-25. 
tabeli 4 ukazano wysokość stopy bezrobocia rejestrowanego w latach 1990-2013, której poziom wahał się w przedziale od 6,9\% w 1990 r. do 19,1\% w 2004 r., kiedy to osiagnęła najwyższą wartość.

W marcu 2014 r. stopa bezrobocia rejestrowanego ukształtowała się na poziomie $16,4 \%$ i była niższa o pół punkta procentowego w odniesieniu do poprzedniego miesiąca. W rankingu województw podkarpackie uplasowało się na dwunastym miejscu pod względem wysokości stopy bezrobocia (najwyższy wskaźnik zanotowano w warmińskomazurskim $-21,5 \%$, a najniższy w wielkopolskim $-9,6 \%)^{21}$.

Tabela 4. Stopa bezrobocia rejestrowanego w województwie podkarpackim w latach 1990-2013 (\%)

\begin{tabular}{|l|c|c|c|c|c|c|c|c|c|c|c|c|}
\hline & $\mathbf{1 9 9 0}$ & $\mathbf{1 9 9 1}$ & $\mathbf{1 9 9 2}$ & $\mathbf{1 9 9 3}$ & $\mathbf{1 9 9 4}$ & $\mathbf{1 9 9 5}$ & $\mathbf{1 9 9 6}$ & $\mathbf{1 9 9 7}$ & $\mathbf{1 9 9 8}$ & $\mathbf{1 9 9 9}$ & $\mathbf{2 0 0 0}$ & $\mathbf{2 0 0 1}$ \\
\hline $\begin{array}{l}\text { Stopa } \\
\text { bezrobocia }\end{array}$ & 6,9 & 13,2 & 15,4 & 17,9 & 17,8 & 16,9 & 14,6 & 12,3 & 12,3 & 14,5 & 16,2 & 17,4 \\
\hline & $\mathbf{2 0 0 2}$ & $\mathbf{2 0 0 3}$ & $\mathbf{2 0 0 4}$ & $\mathbf{2 0 0 5}$ & $\mathbf{2 0 0 6}$ & $\mathbf{2 0 0 7}$ & $\mathbf{2 0 0 8}$ & $\mathbf{2 0 0 9}$ & $\mathbf{2 0 1 0}$ & $\mathbf{2 0 1 1}$ & $\mathbf{2 0 1 2}$ & $\mathbf{2 0 1 3}$ \\
\hline $\begin{array}{l}\text { Stopa } \\
\text { bezrobocia }\end{array}$ & 16,9 & 16,6 & 19,1 & 18,5 & 16,4 & 14,2 & 13,1 & 15,9 & 15,4 & 15,5 & 16,4 & 16,9 \\
\hline
\end{tabular}

Źródło: Opracowanie własne na podstawie: Roczniki statystyczne, GUS z lat 1990-2014.

Tabela 5. Stopa bezrobocia rejestrowanego według BAEL w województwie podkarpackim w latach 2003-2013 (\%)

\begin{tabular}{|l|r|r|r|r|r|r|r|r|r|r|r|}
\hline & $\mathbf{2 0 0 3}$ & $\mathbf{2 0 0 4}$ & $\mathbf{2 0 0 5}$ & $\mathbf{2 0 0 6}$ & $\mathbf{2 0 0 7}$ & $\mathbf{2 0 0 8}$ & $\mathbf{2 0 0 9}$ & $\mathbf{2 0 1 0}$ & $\mathbf{2 0 1 1}$ & $\mathbf{2 0 1 2}$ & $\mathbf{2 0 1 3}$ \\
\hline Ogółem & 20,7 & 19,1 & 17,0 & 12,7 & 8,1 & 7,2 & 10,2 & 10,8 & 13,2 & 14,0 & 15,2 \\
\hline$<$ 24 lat & 43,1 & 40,2 & 42,5 & 32,1 & 20,7 & 21,2 & 35,8 & 30,1 & 41,9 & 41,5 & 47,1 \\
\hline 25-34 lat & 21,9 & 20,7 & 19,8 & 14,5 & 11,3 & 9,1 & 10,6 & 14,4 & 16,6 & 17,1 & 17,2 \\
\hline 35-44 lat & 13,0 & 11,9 & 12,6 & 9,0 & 5,9 & 5,7 & 8,2 & 6,4 & 9,4 & 11,5 & 12,8 \\
\hline 45-54 lat & 11,8 & 11,6 & 10,0 & 8,6 & 5,0 & 4,0 & 6,2 & 7,1 & 7,9 & 7,8 & 8,7 \\
\hline$\geq$ 55 lat & 3,2 & 3,7 & 5,2 & 3,8 & 0,8 & 1,5 & 0,7 & 2,7 & 3,9 & 5,5 & 6,4 \\
\hline
\end{tabular}

Źródło: Opracowanie własne na podstawie: Aktywność ekonomiczna ludności w województwie podkarpackim, Opracowania Urzędu Statystycznego w Rzeszowie z lat 2000-2014.

Wśród bezrobotnych zarejestrowanych w urzędach pracy w województwie podkarpackim dominują osoby, które nie ukończyły 35. roku życia. Problem bezrobocia najmłodszych uczestników rynku jest charakterystyczny dla całego obszaru Unii Europejskiej. W Polsce najwyższy udział osób w wieku 25-34 lat w ogólnej liczbie bezrobotnych odnotowano w województwach: lubelskim (33,2\%), podkarpackim (30,8\%), świętokrzyskim (30,0\%) i wielkopolskim (29,7\%).

W tabeli 5 zaprezentowano stopę bezrobocia rejestrowanego według poszczególnych kategorii wiekowych w latach 2003-2013 w województwie podkarpackim. Dane statystyczne wskazują, że występuje wyraźne zróżnicowanie natężenia bezrobocia w poszczególnych grupach wiekowych.

\footnotetext{
${ }^{21}$ Komunikat o sytuacji społeczno-gospodarczej województwa podkarpackiego w marcu 2014 r.,
} Urząd Statystyczny w Rzeszowie, Nr 3, Rzeszów 2014. 
Praca nierejestrowana...

Tabela 6. Liczba bezrobotnych zarejestrowanych w województwie podkarpackim w latach 19982013 według wieku (tys.)

\begin{tabular}{|c|r|r|r|r|r|r|r|r|}
\hline & \multicolumn{1}{|c|}{$\mathbf{1 9 9 8}$} & \multicolumn{1}{c|}{$\mathbf{1 9 9 9}$} & \multicolumn{1}{c|}{$\mathbf{2 0 0 0}$} & \multicolumn{1}{c|}{$\mathbf{2 0 0 1}$} & $\mathbf{2 0 0 2}$ & \multicolumn{1}{c|}{$\mathbf{2 0 0 3}$} & \multicolumn{1}{c|}{$\mathbf{2 0 0 4}$} & \multicolumn{1}{c|}{$\mathbf{2 0 0 5}$} \\
\hline Ogółem & 137,4 & 164,7 & 182,2 & 195,2 & 187,6 & 182,4 & 170,3 & 164,0 \\
\hline$<24$ lat & 47,8 & 55,4 & 59,8 & 61,4 & 55,4 & 51,0 & 44,7 & 41,0 \\
\hline 25-34 lat & 43,5 & 52,0 & 56,4 & 60,6 & 59,5 & 58,5 & 54,6 & 51,9 \\
\hline 35-44 lat & 32,4 & 38,8 & 43,0 & 45,7 & 43,9 & 42,2 & 39,2 & 37,2 \\
\hline 45-54 lat & 12,4 & 16,9 & 21,1 & 25,0 & 26,0 & 27,5 & 28,1 & 29,1 \\
\hline$\geq 55$ & 1,2 & 1,6 & 1,9 & 2,4 & 2,7 & 3,2 & 3,7 & 4,8 \\
\hline & $\mathbf{2 0 0 6}$ & $\mathbf{2 0 0 7}$ & $\mathbf{2 0 0 8}$ & $\mathbf{2 0 0 9}$ & $\mathbf{2 0 1 0}$ & $\mathbf{2 0 1 1}$ & $\mathbf{2 0 1 2}$ & $\mathbf{2 0 1 3}$ \\
\hline Ogółem & 145,2 & 126,4 & 115,6 & 141,9 & 142,3 & 146,1 & 153,9 & 154,3 \\
\hline$<24$ lat & 33,3 & 27,1 & 26,3 & 35,9 & 34,8 & 34,7 & 35,0 & 32,7 \\
\hline 25-34 lat & 44,9 & 38,4 & 35,5 & 43,0 & 43,9 & 45,6 & 47,7 & 47,0 \\
\hline 35-44 lat & 32,8 & 28,0 & 24,4 & 28,2 & 27,9 & 28,7 & 31,0 & 31,6 \\
\hline 45-54 lat & 28,5 & 26,4 & 23,0 & 26,4 & 26,0 & 25,7 & 26,8 & 27,6 \\
\hline$\geq 55$ & 5,7 & 6,5 & 6,4 & 8,4 & 9,7 & 11,4 & 13,4 & 15,4 \\
\hline
\end{tabular}

Źródło: Biuletyn statystyczny województwa podkarpackiego z lat 2003-2013.

$\mathrm{Na}$ analizowanym obszarze największy problem ze znalezieniem pracy mają osoby młode. Większość populacji bezrobotnych stanowią mieszkańcy, którzy nie przekroczyli 35. roku życia (65\% w 2003 r.; 64,3\% w 2013 r.). Przez pierwsze lata obecnego stulecia w województwie podkarpackim najwyższe bezrobocie wystapiło w grupie wiekowej 15-24 lat, gdzie liczba zarejestrowanych bezrobotnych kształtowała się na poziomie: w 2000 r. 59,8 tys., w 2001 r. - 61 tys. Od 2002 r. grupą wiekową najbardziej dotkniętą problemem braku pracy stały się osoby w wieku 25-34 lat. W 2002 r. 59,5 tys. z tej grupy wiekowej było zarejestrowanych w urzędach pracy, a w 2013 r. - 47,0 tys. osób ${ }^{22}$ (tab. 6).

\section{ZALEŻNOŚĆ MIĘDZY STOPĄ BEZROBOCIA I LICZBĄ MLODYCH OSÓB POZOSTAJĄCYCH BEZ ZATRUDNIENIA A PRACĄ NIEREJESTROWANĄ W WOJEWÓDZTWIE PODKARPACKIM}

W publikacji posłużono się metodą regresji liniowej (metodą estymowania wartości oczekiwanej zmiennej) w celu zbadania, czy między stopą bezrobocia a liczbą młodych osób pozostających bez pracy istnieje zależność statystyczna. Na rysunkach 1-3 przedstawiono wykres rozrzutu, będącego graficzną interpretacją korelacji pomiędzy poziomem nierejestrowanego zatrudnienia a stopa bezrobocia i liczbą bezrobotnych młodych osób w latach 2000-2011 na terenie Podkarpacia. Wszystkie wykresy ilustrują zależność dodatnią, co oznacza, że wzrostowi bezrobocia będzie towarzyszył wzrost zatrudnienia w szarej strefie.

Na rysunku 1 zaprezentowano zależność między stopą bezrobocia a poziomem pracy nierejestrowanej w województwie podkarpackim w latach 2000-2011. Posługując się metodą regresji liniowej, określono linię trendu, której wzór znajduje się w ramce na tle linii siatki wykresu. Pod nim znajduje się współczynnik $\mathrm{R}^{2}$, czyli wskaźnik determinacji.

\footnotetext{
${ }^{22}$ Biuletyn statystyczny województwa podkarpackiego z lat 2003-2013.
} 
Jego wartość wyniosła 0,3931, co oznacza mało istotny związek między obiema zmiennymi.

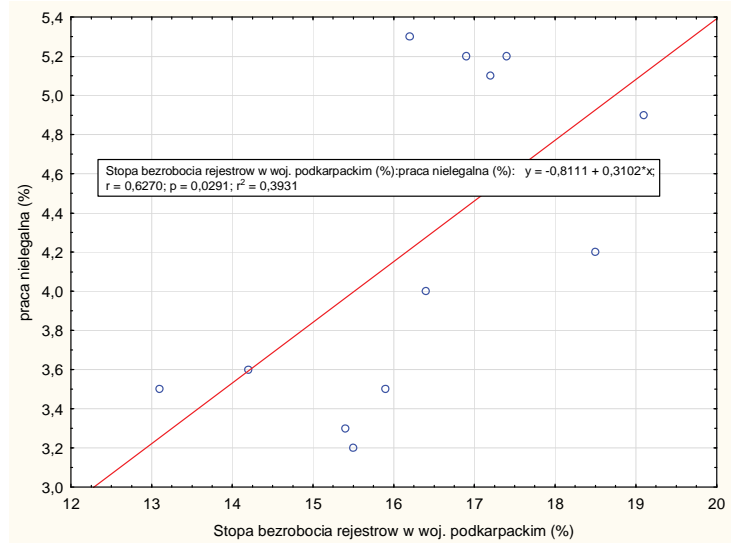

Rysunek 1. Wykres rozrzutu między stopą bezrobocia a poziomem pracy nierejestrowanej w województwie podkarpackim w latach 2000-2011

Źródło: Obliczenia własne na podstawie tabeli 1 oraz tabeli 4.

Rysunek 2 został sporządzony dla najmłodszej grupy osób w wieku do 25. roku życia. Ilustruje on związek między liczbą bezrobotnych a udziałem pracy nierejestrowanej $\mathrm{w}$ PKB we wspomnianej kategorii wiekowej. Wartość wskaźnika determinacji wyniosła w tym wypadku 0,8232 , co oznacza silną $\left(82 \%{ }^{23}\right.$ ) zależność między wzrostem liczby młodych osób pozostających bez pracy a skalą szarej strefy rynku pracy. Równocześnie testy statystyczne potwierdzają, że wykazana zależność nie jest przypadkowym rezultatem, lecz efektem ogólniejszej prawidłowości $\left(p^{* * *}=0,00005\right)$. Najmłodsza grupa wiekowa jest zbiorowością szczególnie podatną i skłonną do pracy w szarej strefie, stąd też w momencie wzrostu jej aktywności na rynku pracy i braku legalnych ofert młodzież przyjmuje ofertę gospodarki nieformalnej - czasami jako jedynej alternatywy. Najmłodsi są także jeszcze często grupą uczącą się i będącą na utrzymaniu rodziców, a równocześnie pracują oni dorywczo, która często wiąże się z sektorem nieformalnym.

Podobnie sytuacja przestawia się w grupie osób w wieku od 25 do 34 lat (rys. 3). W tym wypadku poziom bezrobocia w $82 \%^{24}$ wyjaśnia skalę zatrudnienia nieformalnego. Prawdopodobieństwo testowe kształtuje się na podobnym poziomie $-p^{* * *}$ wyniosło 0,00006 i świadczy o wysokiej istotności statystycznej tej zależności. Osoby z rozpatrywanej kategorii wiekowej zainteresowani są większą stabilizacją zawodową, zakładają rodziny i chcą się uniezależnić finansowo. W województwie podkarpackim jest to jednak szczególnie trudne ze względu na wysoki poziom bezrobocia i brak nowych miejsc pracy, dlatego częstą alternatywą staje się zatrudnienie nierejestrowane.

${ }^{23}$ Zależność ta liczona dla tego samego okresu czasowego i tej samej kategorii wiekowej osób z terenu całej Polski wyniosła 0,9089 i świadczyła o bardzo wysokiej zgodności statystycznej obu zmiennych.

${ }^{24}$ Zależność ta liczona dla populacji całego kraju w tej kategorii wiekowej byłą nieznacznie niższa wskaźnik determinacji osiagnął poziom 0,7197. 


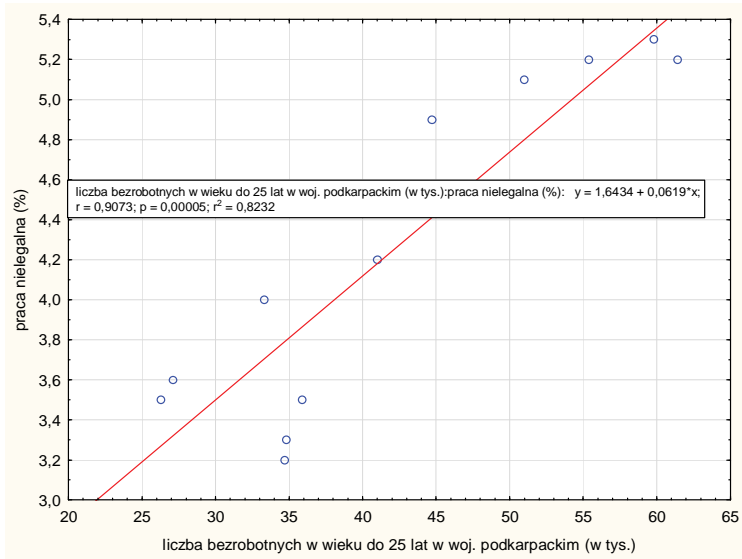

Rysunek 2. Wykres rozrzutu między liczbą bezrobotnych w wieku poniżej 25 lat a poziomem pracy nierejestrowanej w województwie podkarpackim w latach 2000-2011

Źródło: Obliczenia własne na podstawie tabeli 1 oraz tabeli 6.

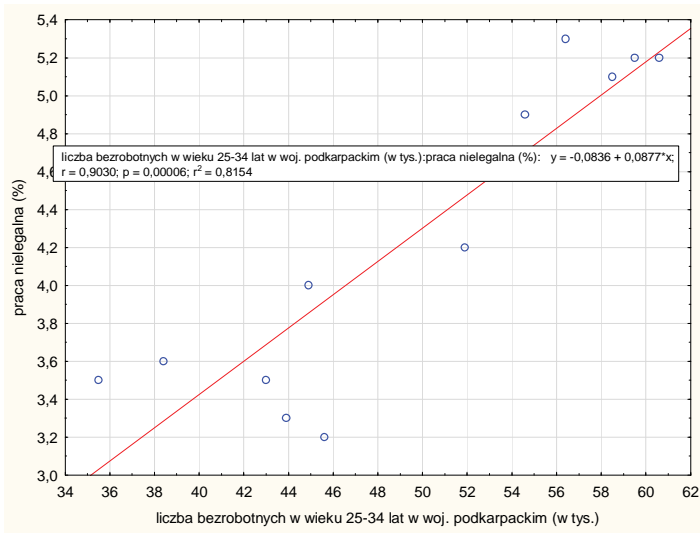

Rysunek 3. Wykres rozrzutu między liczbą bezrobotnych w wieku 25-34 lat a poziomem pracy nierejestrowanej w województwie podkarpackim w latach 2000-2011

Źródło: Obliczenia własne na podstawie tabeli 1 oraz tabeli 6.

\section{SKUTKI BEZROBOCIA WŚRÓD MLODYCH OSÓB Z WOJEWÓDZTWA PODKARPACKIEGO W ŚWIETLE BADAŃ EMPIRYCZNYCH}

$\mathrm{Na}$ pracę nierejstrowaną jako skutek bezrobocia wskazują własne badania ankietowe $\mathrm{z}$ lat 2007-2014 dotyczace zjawiska szarej strefy, w tym pracy nieformalnej ${ }^{25}$.

\footnotetext{
${ }^{25}$ Badania własne przeprowadzono na celowej próbie 686 gospodarstw domowych (w maju 2007 r.), 750 gospodarstw domowych (w maju 2009 r.), 1084 gospodarstw domowych (w kwietniu i maju 2010 r.), 1201 gospodarstw domowych (w maju 2011 r.), 1230 gospodarstw domowych (w styczniu 2012 r.), 1128 gospodarstw (w styczniu 2013 r.) oraz 857 gospodarstw domowych (w
} 
Taka forma metody bezpośredniej pozwala na jakościową analizę problemu. W literaturze przedmiotu przyjmuje się, że oprócz wielu wad tej metody, badania tego typu są najlepszym narzędziem, jakie obecnie można wykorzystać do analizy struktury nieformalnego rynku pracy, jego determinantów oraz identyfikacji przyczyn zjawiska ${ }^{26}$.

W tabeli 7 przedstawiono strukturę odpowiedzi na pytanie o najistotniejsze skutki bezrobocia. Zdaniem osób biorących udział w badaniu najważniejszą konsekwencją braku pracy są migracje zagraniczne (32\% w 2013 r., 27,4\% w 2014 r.). Taki wariant dopowiedzi wybrała co czwarta osoba w wieku poniżej 25 lat i co piąta w wieku 25-34 lat. Z emigracją zarobkową wiążą się straty nie tylko ekonomiczne, ale także demograficzne. Młodzi ludzie i ich dzieci mieszkające poza Polską niekorzystnie oddziałują na strukturę wiekową starzejącego się społeczeństwa polskiego. Respondenci zwrócili też szczególną uwagę na patologie społeczne. Zdaniem 26,4\% ankietowanych jest to ważny skutek bezrobocia.

Tabela 7. Struktura odpowiedzi na pytanie: „Jakie Pana/Pani zdaniem są najważniejsze skutki bezrobocia?"

\begin{tabular}{|c|c|c|c|c|}
\hline \multirow{2}{*}{ Opinia } & \multicolumn{2}{|c|}{ Liczba osób } & \multicolumn{2}{|c|}{$\begin{array}{c}\text { Struktura } \\
\text { procentowa }\end{array}$} \\
\hline & 2013 & 2014 & 2013 & 2014 \\
\hline $\begin{array}{c}\text { Wzrost negatywnych zjawisk społecznych (przestępczość, konflikty z } \\
\text { prawem, alkoholizm) }\end{array}$ & 271 & 227 & $24,0 \%$ & $26,5 \%$ \\
\hline Migracje zagraniczne & 362 & 235 & $32,1 \%$ & $27,4 \%$ \\
\hline $\begin{array}{c}\text { Dorabianie „,na czarno” (bez prawa do urlopu, bez składek ubezpieczenia } \\
\text { zdrowotnego itp.) }\end{array}$ & 115 & 137 & $10,2 \%$ & $16,0 \%$ \\
\hline Obniżenie standardu życia osób bezrobotnych i ich rodzin & 129 & 74 & $11,5 \%$ & $8,6 \%$ \\
\hline Izolowanie się od ludzi, depresja & 67 & 55 & $6,0 \%$ & $6,4 \%$ \\
\hline Spadek zainteresowania życiem publicznym & 31 & 19 & $2,8 \%$ & $2,2 \%$ \\
\hline Życie z zasiłków dla bezrobotnych i odzwyczajanie się od pracy & 49 & 44 & $4,3 \%$ & $5,1 \%$ \\
\hline $\begin{array}{c}\text { Bez pracy młodzi absolwenci nie mogą rozpoczać samodzielnego życia i } \\
\text { ustabilizować swojej sytuacji materialnej }\end{array}$ & 67 & 56 & $5,9 \%$ & $6,5 \%$ \\
\hline Bezrobocie poprawia stosunek ludzi do pracy & 5 & 4 & $0,4 \%$ & $0,5 \%$ \\
\hline Dyskryminacja, konflikty społeczne & 18 & 6 & $1,6 \%$ & $0,7 \%$ \\
\hline RAZEM & 1128 & 857 & $100,0 \%$ & $100,0 \%$ \\
\hline Brak odpowiedzi & 14 & 0 & $1,2 \%$ & $0 \%$ \\
\hline
\end{tabular}

Źródło: Obliczenia własne na podstawie danych z badań ankietowych przeprowadzonych w latach 2013-2014.

Zjawisko bezrobocia rodzi także przesłanki do rozwoju szarej strefy rynku pracy, która jest najważniejszym skutkiem bezrobocia według $16 \%$ osób biorących udział w badaniu w 2014 r. Na podstawie analizy odpowiedzi według wieku ankietowanych niepokój budzi fakt, że na pracę nierejestrowaną jako konsekwencję braku pracy zwracała uwagę niemal co czwarta młoda osoba w wieku do 25 lat (w grupie wiekowej 36-50 był to najważniejszy skutek bezrobocia - 29,2\% osób w tej kategorii wiekowej wybrało ten wariant odpowiedzi).

styczniu 2014 r.). W badaniach ankietowych przeprowadzonych w maju 2007 r. wzięły udział gospodarstwa domowe $\mathrm{z}$ terenu całej Polski, natomiast wywiady w latach 2009-2014 przeprowadzono na terenie województwa podkarpackiego. Ankiety były skierowane do osób powyżej 20. roku życia o zróżnicowanym poziomie dochodów oraz standardzie życia.

${ }^{26}$ M. Bednarski, E. Kryńska, K. Pater, M. Walewski, Przyczyny pracy nierejestrowanej w Polsce, Ministerstwo pracy i Polityki Społecznej, IPiSS, COBOS, CASE, MillwardBrown SMG/KRC, Warszawa 2008, s. 56. 


\section{WNIOSKI}

Bezrobocie jest zjawiskiem, które dotyczy, mimo zróżnicowanej liczby bezrobotnych, całego kraju. Regionem, który od lat dotyka ten problem, jest województwo podkarpackie. Równocześnie osoby, które dominują wśród zarejestrowanych bezrobotnych $\mathrm{w}$ urzędach pracy, to osoby młode, niemające ukończonych 35 lat. Posiadanie statusu bezrobotnego potęguje wiele negatywnych następstw rozpatrywanych w aspekcie: ekonomicznym, społecznym oraz indywidualnym. Najistotniejszym skutkiem gospodarczym jest obniżenie poziomu wzrostu gospodarczego, spowolnienie tempa rozwoju ekonomicznego i wystąpienie tzw. luki produkcyjnej będącej efektem niewykorzystania potencjału produkcyjnego kraju.

Konsekwencjami braku pracy dla większości bezrobotnych są pogorszenie standardu życia, problemy z zagospodarowaniem czasu wolnego, izolacja społeczna, ograniczenie lub zaniechanie uczestnictwa w życiu kulturalnym i politycznym. Skutkiem są także często wzrost przestępczości, rozpad rodziny, migracje zagraniczne z ich dalekosiężnymi skutkami.

Utrzymywanie się wysokiego bezrobocia stwarza sprzyjające warunki do rozwoju gospodarki nieformalnej i zatrudnienia poza ewidencją. Osoby niemogące znaleźć legalnej pracy szukają zatrudnienia w sektorach, które działają poza prawem i kontrolą władz fiskalnych. W ten sposób państwo traci znaczne dochody podatkowe, a przy tym jest obciążone z tytułu wypłat zasiłków i innych świadczeń na rzecz bezrobotnych.

Wielkość pracy nierejestrowanej według szacunków GUS na Podkarpaciu kształtuje się w granicach od $450 \mathrm{mln}$ zł w 1994 r. do $1824 \mathrm{mln}$ zł w 2011 r. Poziom stopy bezrobocia oraz liczba osób niemająca zatrudniania, liczona według BAEL, plasują Podkarpacie na jednym z pierwszych miejsc w kraju. Statystyki sygnalizują niepokojące zjawisko braku pracy wśród najmłodszych uczestników rynku pracy. Jest to grupa szczególnie wrażliwa na skutki bezrobocia, a także najbardziej skłonna do pracy w sektorze nieformalnym. Także badania ankietowe potwierdzają, że konsekwencją braku zatrudnienia może być szukanie alternatywnych form - między innymi pracy nierejestrowanej. Przeprowadzone analizy statystyczne zdają się potwierdzać wysoką zależność pracy nielegalnej z poziomem bezrobocia - w ponad $80 \%$ liczba bezrobotnych determinuje aktywność w szarej strefie rynku pracy.

Ocena skutków bezrobocia jest trudna, ponieważ zależy nie tylko od długości okresu pozostawania bez pracy, ale także od indywidualnych cech danej osoby i jej otoczenia. Wydaje się jednak, że bezrobocie, zwłaszcza długookresowe, świadczy o ułomności systemu gospodarczego i można je uznać za zjawisko patologiczne, gdyż pozbawia ono możliwości zaspokojenia jednej z podstawowych potrzeb - potrzeby pracy.

\section{LITERATURA}

[1] Analiza sytuacji na rynku pracy w województwie podkarpackim, Wojewódzki Urząd pracy w Rzeszowie, Rzeszów 2012.

[2] Barro R.J., Economic Growth in a Cross Selection of Countries, „Quarterly Journal of Economics", May 1991.

[3] Bąk E., Nietypowe formy zatrudnienia na rynku pracy, C.H. Beck, Warszawa 2009.

[4] Bednarski M., Kryńska E., Pater K., Walewski M., Przyczyny pracy nierejestrowanej $w$ Polsce, Ministerstwo Pracy i Polityki Społecznej, IPiSS, COBOS, CASE, MillwardBrown SMG/KRC, Warszawa 2008. 
[5] Dach Z., Bezrobocie w okresie przemian systemowych gospodarki polskiej, PAN, Warszawa 1993.

[6] Hall R.E., Taylor J.B., Makroekonomia, PWN, Warszawa 2002.

[7] Kabaj M., Strategie i programy przeciwdziataniu bezrobociu w Unii Europejskiej $i$ w Polsce, SCHOLAR, Warszawa 2004.

[8] Komunikat o sytuacji spoteczno-gospodarczej województwa podkarpackiego $w$ marcu 2014 r., Urząd Statystyczny w Rzeszowie, Nr 3, Rzeszów 2014.

[9] Kubiak E., Nakonieczna-Kisiel H., Makroekonomiczne podstawy polityki gospodarczej, Wydawnictwo Samorządowe FRDL, Warszawa 1999.

[10] Kwiatkowski E., Bezrobocie. Podstawy teoretyczne, PWN, Warszawa 2002.

[11] M. Cieślukowski, Ekonomiczne skutki i metody ograniczania bezrobocia, „Ruch Prawniczy, Ekonomiczny i Społeczny" 1998/3-4.

[12] M. Pasternak-Malicka, Przestanki ruchów migracyjnych Polaków z obszaru województwa podkarpackiego w kontekście kryzysu gospodarczego wywołanego kryzysem subprime, „Ekonomia, Prace Naukowe Uniwersytetu Ekonomicznego we Wrocławiu" 2013/305.

[13] M. Pasternak-Malicka, Przyczyny i skutki migracji zagranicznych młodych Polaków, [w:] Wspótczesne problemy ekonomiczne, „Zeszyty Naukowe Uniwersytetu Szczecińskiego" 2013/787.

[14] Mindur M., Kontrowersje i sporne kwestie dotyczace bezrobocia w Polsce, ,Studia i prace Kolegium Zarządzania i Finansów SGH” 2007/84.

[15] Nowe zadania polityki społecznej. Patologie i dysfunkcje wybranych obszarów życia spotecznego, red. E. Trafiałek, PWSZ, Tarnobrzeg 2006.

[16] Okun A. M., Ceny i ilości. Analiza makroekonomiczna, PWN, Warszawa 1991.

[17] Pasternak-Malicka M., Zatrudnienie nierejestrowane $w$ kontekście problematyki bezrobocia, [w:] Praca Polaków, red. B. Kłos, A. Grycuka, Biuro Analiz Sejmowych Kancelarii Sejmu, Studia BAS, 4(36), Warszawa 2013.

[18] Rachunki narodowe wg sektorów i podsektorów instytucjonalnych 2005-2008, Aneks 4: Szara strefa w rachunkach narodowych, Warszawa 2010.

[19] Rynek pracy w Polsce $w$ dobie integracji i globalizacji, red. M. Noga, M.K. Sawicka, Cedetu, Warszawa 2009.

[20] Schneider F., Shadow Economies and Corruption All Over the World: New Estimates for 145 Countries, Johannes Kepler University of Linz, Austria, 24 July 2007.

[21] Socha M., Sztanderska U., Strukturalne podstawy bezrobocia w Polsce, PWN, Warszawa 2002.

[22] Stecko J., Prywacyjna koncepcja zła $w$ interpretacji Leszka Kołakowskiego, „Humanities and Social Sciences” 20/1 (2013).

[23] Stecko J., W poszukiwaniu pierwszej przyczyny zła - filozofia Mariana Zdziechowskiego, „Humanities and Social Sciences” 20/3 (2013).

[24] Torgler B., Schneider F., Shadow Economy, Tax Morale, Governance and Institutional Quality: A panel Analysis, IZA Discussion Paper Series 2007.

\section{ILLEGAL WORK AS A RESULT OF THE PHENOMENON OF}

\section{UNEMPLOYMENT AMONG YOUNG PEOPLE IN PODKARPACKIE PROVINCE}

Political and economic transformation in Poland caused a fundamental transformation in the labor market. The phenomenon of open unemployment, unknown in Poland before 1990, began to manifest itself on a large scale with the launch of market mechanisms in the economy. The highlight of the level of unemployment was recorded in 2002-2005, when in some months, the unemployment rate exceeded $19-20 \%$. At the same a time dangerous 
feature of not only the Polish labor market is the high proportion of young unemployed people. The consequences of unemployment is mostly dealt with at the economic, legal and political level. However, one should not only forget about the health, psychological and moral aspect in relation to single persons without work, as well as their families. Often a result of lack of legal labor becomes illegal work as the only available alternative. One of the regions significantly affected by the lack of work is Podkarpackie Province.

The paper presents the nature and scale of illegal work in Poland and Podkarpackie Province. There are described social and economic consequences of unemployment and the level of unemployment by age structure in the region. The aim of the publication is an attempt to assess whether illegal work is the result of growing in recent years, the phenomenon of unemployment among young people living in Podkarpackie Province.

Keywords: labor market, undeclared work, unemployment.

DOI:10.7862/rz.2014.hss.63

Przesłano do redakcji: czerwiec 2014

Przyjęto do druku: grudzień 2014 